\title{
Clinical profiles and some associated factors of Japanese encephalitis in Bali
}

\author{
I Komang Kari, Wei Liu, I Made Kompiang Gautama, I Ketut Subrata, Zhi Yi Xu
}

\begin{abstract}
Background Japanese Encephalitis (JE) is a mosquito-borne viral disease that can affect the central nervous system and cause several complications and death. In Indonesia, particularly in Bali, studies of JE in humans are still very limited.

Objective To assess the clinical manifestations and outcome of $\mathrm{JE}$ in Bali and to identify some possible associated factors and monthly distribution of admission to the hospitals.

Methods A cross-sectional study was conducted in 8 district hospitals, army hospital, and Sanglah central hospital, as surveillance centers in Bali, from July 2001 through January 2003. Subjects less than 12 years of age and residences of Bali province who were suspected of having acute viral encephalitis, aseptic meningitis, and acute flaccid paralysis referred from all health facilities were included in this study. The diagnosis of JE was established by detection of virus-specific IgM in CSF and serum, with IgM capture enzyme-linked immunosorbent assay (MAC ELISA)

Results During the study, 158 subjects with encephalitis were included; 55 (34.8\%) were caused by JE and 103 (65.2\%) were caused by non-JE. It showed that pig owning and rice farming were significantly associated with JE $(\mathrm{PR}=3.02,95 \% \mathrm{Cl} 1.29 ; 7.10 ; \mathrm{P}=0.009$ and $\mathrm{PR}=2.86,95 \% \mathrm{Cl} 1.30 ; 6,31, \mathrm{P}=0.008$, respectively). Most subjects $(46.2 \%)$ were under 2 years old with mean age of 37.24 (SD 32.24) months. Forty-two (26.6\%) subjects had nuchal rigidity, and all of them had aseptic meningitis. Denpasar had the highest prevalence of non-JE cases. Bangli and Klungkung had the lowest prevalence of JE and non-JE. The highest prevalence of JE was in Gianyar. Peak prevalences of JE were in April and May 2002. Peak prevalences of non-JE were during August-October 2001 and in March-April 2002. Four (7.3\%) subjects of JE group and 25 (24.3\%) subjects of non-JE died. There were $25(45.5 \%)$ out of 55 subjects who survived with disability. Twenty-four (43.6\%) JE subjects and $34(33.0 \%)$ non-JE subjects had good outcome.

Conclusions Around one third of the subjects were positively diagnosed as JE. The highest prevalence of JE was found in Gianyar. Peak prevalences of JE are in April and May 2002. Pig owning and rice farming are associated factors. Almost half of JE subjects survived with disability [Pediatr Indones 2006;46:13-19].
\end{abstract}

Keywords: Japanese encephalitis, cerebrospinal fluid, Mac Elisa, Bali
J apanese Encephalitis (JE) is a zoonosis disease where the Japanese Encephalitis Virus (JEV) most commonly infects domestic animals, birds, bats, snakes, and frogs, although it infects human beings by accident. It is one of several mosquito-borne viral diseases that affects the central nervous system and causes several complications and death. JEV has a complex lifecycle which involves domestic pigs and specific types of mosquito, Culex tritaeniorhynchus, which lives in rural rice-growing and pig-farming regions. ${ }^{1}$

Many areas in Asia, including Japan, Korea, China, India, Thailand, Indonesia, Malaysia, Vietnam, Taiwan, and Philippines, where the disease-causing arbovirus is always present, are endemic for JE. In Japan, during the period of 1948 to 1959 in summer, $3687 \mathrm{JE}$ patients were reported and $42 \%$ died, where the highest occurred in $1950^{2}$ and derived from rural areas. ${ }^{3,4}$ The majority of JE patients were children less than 15 years and the peak age was $1-5$ years $(45 \%)^{5}$ with the case fatality ratio $33 \% 5$ where male is dominant. ${ }^{4,6} \mathrm{JE}$ patients have unfavorable neurological sequelae from $30-50 \% .4,6$ According to MRI findings,

From the Department of Child Health, Medical School, Udayana University, Bali, Indonesia (IKK); International Vaccine Institute, Seoul, Korea (WL); Indonesian Pediatric Association, Bali Branch (IMKG); Center for Disease Control and Prevention, Bali, Indonesia (IKS, ZYX).

Reprint requests to: I Komang Kari, Department of Child Health, Medical School, Udayana University, Sanglah Hospital, Jl. P. Nias, Denpasar, Bali, Indonesia. Tel/Fax. 62-361-244038. 
JE patients showed lesions in the thalamus, cortex, midbrain, cerebellum, and spinal cord. ${ }^{7}$ If the virus attacks the spinal cord, acute flaccid paralysis (AFP) may occur. ${ }^{8}$

In Indonesia, study of JE in human is still limited. Lubis ${ }^{9}$ reported 118 children, with clinically suspected JE by serological confirmation with haemagglutination inhibition (HI) and immune adherence haemogglutination (IAHA) tests, showed a 4-fold increase against JE antigen in 30 (25.4\%) subjects. Until recently, there is no JE study which covers all district hospitals in the Bali province, except one JE study conducted by Kari ${ }^{10}$ during the period of October 1990 to July 1995 which reported 40 (51.9\%) JE subjects of 77 acute viral encephalitis in Sanglah hospital. The aim of this study was to assess the clinical manifestations and outcome of JE in Bali. In addition, to identify some possible associated factors and monthly distribution of hospital admissions.

\section{Methods}

This cross-sectional study was conducted in 8 district hospitals, Army hospital Denpasar, and Sanglah central hospital as surveillance centers in Bali, from July 2001 through January 2003. The study protocol was approved by General Director of Disease Control and Environmental Health, Ministry of Health Indonesia, Bali Governor, and Bali Health Office.

The subjects were patients aged 0 to 12 years with the diagnosis of suspected acute viral encephalitis, aseptic meningitis, and acute flaccid paralysis, referred from all health facilities in Bali providing health care such as sub-district health centers, village health clinics, and private hospitals and clinics, for further evaluation and treatment. Before the study started, a series of workshops were provided for all pediatricians and general practitioners to increase the awareness of the disease and to refer them to surveillance centers. Clinically, suspected encephalitis or aseptic meningitis was defined as those with acute onset of fever (axillary temperature $>38^{\circ}$ ), with any neurologic deficits (including changes in mental status or level of consciousness, cranial nerve deficits, motor or sensory system deficits), and had one or more signs or symptoms, such as neck stiffness, sei- zures (convulsions), bulging anterior fontanel, vomiting, headache (in children aged $\geq 5$ years), generalized malaise, dizziness, coryza, nausea, and diarrhea. The final diagnosis of encephalitis or aseptic meningitis was confirmed by the result of cerebrospinal fluid (CSF) examination which was colorless, clear to opalescence turbidity, Nonne $-/+$, Pandy $-/+$, amount of cells 10 to hundreds $/ \mathrm{mm}^{3}$ with mononuclear cells predominantly, normal glucose, and elevated protein. AFP is characterized by rapid onset of weakness of extremities, often including weakness of respiration and swallowing muscles, progressing to maximum severity within 1 to 10 days.

Written informed consent was obtained from the patients' parents who agreed to participate in the study and for lumbar and venous punctures at admission. When possible, follow up of CSF and blood specimens were obtained 1-2 weeks later. The specimens were kept in freezer in the district hospital and the team of field workers picked it up and stored it at $-70^{\circ} \mathrm{C}$ prior to JE assay at central public health laboratory in Denpasar, Bali. Patients were excluded from the study if proven to have bacterial meningitis, sepsis, malaria, brain abscess, or tumor.

After the diagnosis of encephalitis, aseptic meningitis, or AFP were confirmed, the diagnosis of JE was established by detection of virus-specific IgM in CSF and serum, with IgM capture enzyme-linked immunosorbent assay (MAC ELISA), described by Burke and Nisalak. ${ }^{11,12}$ Subjects were considered as confirmed JE if anti-JE virus IgM antibody was present in CSF (1:10 dilution), and they were considered as probable JE if anti-JE virus IgM was detected only in serum (1:100 dilution). Since the dengue virus was also endemic in the same study area, the IgM capture ELISA was not specific to differentiate recent JE virus infection from another Flavivirus infection; therefore, an IgM capture ELISA for dengue virus was performed on all specimens. ${ }^{13}$ Laboratory tests for JE diagnosis was carried out at central public health laboratory in Denpasar, Bali. External confirmations of ELISA results were blinded and performed on a sample of specimens at the reference laboratory of the Armed Forces Research In Medical Sciences (AFRIMS). The probable JE was included in non-JE cases. To determine the exact distribution of JE in each district area, the result of JE patients at Sanglah central hospital were distributed to the subject's original location. 
To determine whether sex, pig owning, and rice farming are associated factors for JE versus non-JE, cross tabulation analysis was performed using prevalence ratio, and chi-square test to show its strength of relationship and statistical significance. Statistical analysis was performed using SPSS for Windows, version 10.0. Statistical significance was taken at $\mathrm{P}<0.05$, and $95 \% \mathrm{CI}$ was also calculated to show precision.

\section{Results}

There were 161 subjects of encephalitis during the study period. Three subjects were excluded (1 due to malaria, 1 bacterial meningitis, and 1 septicemia). All of the remaining subjects had viral encephalitis and aseptic meningitis, and there were no AFP. Fifty-five subjects (34.8\%) had JE and 103 subjects (65.2\%) had non-JE (Table 1).

TABle 1. Distribution of encephalitis (VIRAL AND ASEPTIC) AMONG JE AND NON-JE CASES

\begin{tabular}{lccc}
\hline \multicolumn{1}{c}{ Diagnosis } & JE (\%) & Non-JE (\%) & Total (\%) \\
\hline Viral encephalitis & $39(33.6)$ & $77(66.4)$ & $116(73.4)$ \\
Aseptic meningitis & $16(38.1)$ & $26(61.9)$ & $42(26.6)$ \\
\hline \multicolumn{1}{c}{ Total } & $55(34.8)$ & $103(65.2)$ & $158(100)$ \\
\hline
\end{tabular}

In the analysis of association between the factors and presence of JE, it was shown that sex was not associated with the presence of JE; however, owning pig and rice farming were significantly associated $(\mathrm{PR}=3.02,95 \% \mathrm{CI}: 1.29 ; 7.10, \mathrm{P}=0.009 / \mathrm{PR}=2.86$, $95 \%$ CI:1.30; 6.31, $\mathrm{P}=0.008$, respectively) (Table 2).

Most subjects (69.6\%) were well-nourished, $6.3 \%$ over weight, and $24.1 \%$ malnourished. Based on nutritional status, there were no significant difference $(\mathrm{P}=0.069)$.
The distribution of JE and non-JE subjects according to age showed that most $(46.2 \%)$ were under 2 years old [mean 37.24 (SD 32.24) months] and the range was 4-125 months. There was a statistically significant difference in the distribution based on age groups $(\mathrm{P}=0.001)$ (Table 3$)$.

All subjects (100\%) had fever and decreased consciousness. Forty-two (26.6\%) had nuchal rigidity, and all subjects had aseptic meningitis. Other clinical manifestations are shown in Table 4.

With regards to area distribution, Denpasar was the area with the highest prevalence of non-JE cases, while Bangli and Klungkung had the lowest prevalence of JE and non-JE (Figure 1). The highest prevalence of JE was in Gianyar, while Tabanan and Karangasem had the same prevalence.

Based on the time of admission, the peak prevalence of JE were in April and May 2002. In the nonJE group, the peak prevalence were during the period of August-October 2001 and during March-April 2002 (Figure 2).

Regarding the outcome of disease, 4 (7.3\%) subjects of JE and 25 (24.3\%) subjects of non-JE group died. Twenty-five out of 55 subjects (45.5\%) survived with disabilities. Twenty-four (43.6\%) subjects with JE and 34 (33.0\%) non-JE had good outcome (Table 5).

\section{Discussion}

In our study, aseptic meningitis due to JEV was 16 of 55 JE (29.1\%) subjects. There was also aseptic meningitis due to non-JEV which had not been tested yet. Infections with JEV can be asymptomatic, resulting in mild febrile illness or aseptic meningitis, or presented as severe meningomyeloencephalitis. ${ }^{14}$ The viral causes of aseptic meningitis are enteroviruses (e.g. Coxsackie B, echoviruses, polioviruses), mump

Table 2. The association of some possible associated factors With THE PRESENCE OF JE VS NON-JE

\begin{tabular}{lccccc}
\hline Associated factors & $\begin{array}{c}\text { JE } \\
(\mathbf{n}=\mathbf{5 5})\end{array}$ & $\begin{array}{c}\text { Non-JE } \\
(\mathbf{n}=\mathbf{1 0 3})\end{array}$ & $\begin{array}{c}\text { Prevalence } \\
\text { ratio }\end{array}$ & $\mathbf{P}$ & $\mathbf{9 5 \%} \mathbf{C l}$ \\
\hline Sex (male) & 28 & 52 & 1.01 & 0.960 & $0.53 ; 1.96$ \\
Pig owning & 47 & 68 & 3.02 & 0.009 & $1.29 ; 7.10$ \\
Rice farming & 45 & 63 & 2.86 & 0.008 & $1.30 ; 6.31$ \\
\hline
\end{tabular}


Table 3. Distribution of age in JE and nON-JE

\begin{tabular}{lccc}
\hline Age (years) & $\begin{array}{c}\text { JE (\%) } \\
\mathbf{n = 5 5}\end{array}$ & $\begin{array}{c}\text { Non-JE (\%) } \\
\mathbf{n = 1 0 3}\end{array}$ & $\begin{array}{c}\text { Total } \\
(\%)\end{array}$ \\
\hline$<2$ & $15(20.5)$ & $58(79.5)$ & $73(46.2)$ \\
$2-4$ & $13(34.2)$ & $25(65.8)$ & $38(24.1)$ \\
$>4-6$ & $12(60)$ & $8(40)$ & $20(12.7)$ \\
$>6-8$ & $8(50)$ & $8(50)$ & $16(10.1)$ \\
$>8-10$ & $7(70)$ & $3(30)$ & $10(6.3)$ \\
$>10-12$ & $0(0)$ & $1(100)$ & $1(0.6)$ \\
\hline \multicolumn{1}{c}{ Total } & 55 & 103 & 158 \\
\hline
\end{tabular}

$X^{2}=19.760 ; d f=5, P=0.001$

Table 4. Clinical manifestations of JE and nON-JE

\begin{tabular}{lcc}
\hline Clinical manifestation & $\begin{array}{c}\text { JE (\%) } \\
\mathbf{n}=\mathbf{5 5}\end{array}$ & $\begin{array}{c}\text { Non-JE (\%) } \\
\mathbf{n}=\mathbf{1 0 3}\end{array}$ \\
\hline Fever & $55(100)$ & $103(100)$ \\
Decrease of mental status & $55(100)$ & $103(100)$ \\
Coryza & $2(3.6)$ & $7(6.8)$ \\
Diarrhea & $0(0)$ & $4(3.9)$ \\
Nuchal rigidity & $16(29.1)$ & $26(25.2)$ \\
Vomiting & $32(58.2)$ & $63(61.2)$ \\
Convulsion & $50(90.9)$ & $92(89.3)$ \\
Bulging fontanel & $2(3.6)$ & $17(16.5)$ \\
Headache* & $21(52.5)$ & $19(47.5)$ \\
\hline
\end{tabular}

* For children $\geq 5$ years old $(n=40)$

Table 5. Distribution of outcome in JE and non-JE

\begin{tabular}{lcc}
\hline \multicolumn{1}{c}{ Outcome } & $\begin{array}{c}\text { JE (\%) } \\
\mathbf{n = 5 5}\end{array}$ & $\begin{array}{c}\text { Non-JE (\%) } \\
\mathbf{n = 1 0 3}\end{array}$ \\
\hline Dead & $4(7.3)$ & $25(24.3)$ \\
Alive with disability & $25(45.5)$ & $32(31.0)$ \\
Alive sick & $2(3.6)$ & $12(11.7)$ \\
Alive well & $24(43.6)$ & $34(33.0)$ \\
\hline
\end{tabular}

virus, herpesvirus hominis (type 2 strain), and the lymphocytic choriomeningitis virus. ${ }^{15}$

In our study, most parents raised pigs near their house and lived near rice fields (distance between house and rice field $<100 \mathrm{~m}$ ). JE prevalence in Denpasar was the second highest after Gianyar although people in Denpasar rarely raised pigs near their house. Bali has established a unique irrigation system called subak. The water is efficiently distributed for cultivating rice fields between each subak which rotates the water for the rice field. Thus, the Balinese rice field is cultivated three times annually resulting in permanent breeding site for the principle mosquito species of Culex tritaeniorhiynchis, Culex gelidus, and Culex fuscocephala which have been incriminated as vectors in Bali. ${ }^{16}$ In rural areas, each Balinese family raises one or more pigs in their backyard which may amplifying hosts as JE reservoir. The mobility of people from rural to urban, vice versa, was high and easily done since the farthest district in Bali island can be reached in 3 hours by car from Denpasar. Therefore, the tropical environment, agricultural practices, and behavior in Bali facilitated the year round transmission of JEV through host-mosquito cycle in rural as well as in urban area.

In our study of $55 \mathrm{JE}$ subjects, 25 (45.5\%) were children aged 2 to 6 years. The older the age, the lower the morbidity of JE. No JE was found in the age of 10 to 12 years old. The result that higher morbidity occured among children aged 3 to 6 years is consistent with the higher risk in this group due to behavioral factor. It could be explained that children may spend more time outside the house playing with their peers in dusty conditions, allowing an increase of exposure. ${ }^{14}$ Tapering off age-specific attack rates after the age of age 14 years is accompanied by increased prevalence of neutralizing antibody in this age group, indicating that the reduced attack rates in heavily affected population is due to immunity resulting from natural exposure and subclinical infection. ${ }^{17}$

Before and during admission day, all JE subjects had fever and decreased mental status. This was similar to that found by Kumar ${ }^{18}$ (fever $94.5 \%$ and coma grade I, II, III 100\%) in children aged 0 to 12 years in endemic areas of JE in northern India. In contrast, nuchal rigidity was observed more frequently, i.e. $29.1 \%$ as compared to only $13 \%$ reported by $\operatorname{Kumar}^{18}$ yet less than that reported by Rao, ${ }^{19}$ i.e. $48 \%$ of subjects. Vomiting occurred in $58.2 \%$ of our JE subjects, similar to that found by Kumar, ${ }^{18}$ i.e. $54.3 \%$. Convulsion was observed in $90.9 \%$ in our study, similar to that found in studies by $\operatorname{Kumar}^{18}$ and Rao, ${ }^{19}$ i.e. $84.7 \%$ and $92 \%$, respectively. In susceptible individuals, JEV invades parts of the central nervous system, such as brain parenchym and meningen through a complex process; JEV enters and replicates within neuron as well as meningen. This infectious process will result in clinical manifestation of JE such as fever, loss of consciousness, meningeal irritation, vomiting, convulsion, and headache. 
I Komang Kari et al: Clinical profiles and some associated factors of Japanese encephalitis

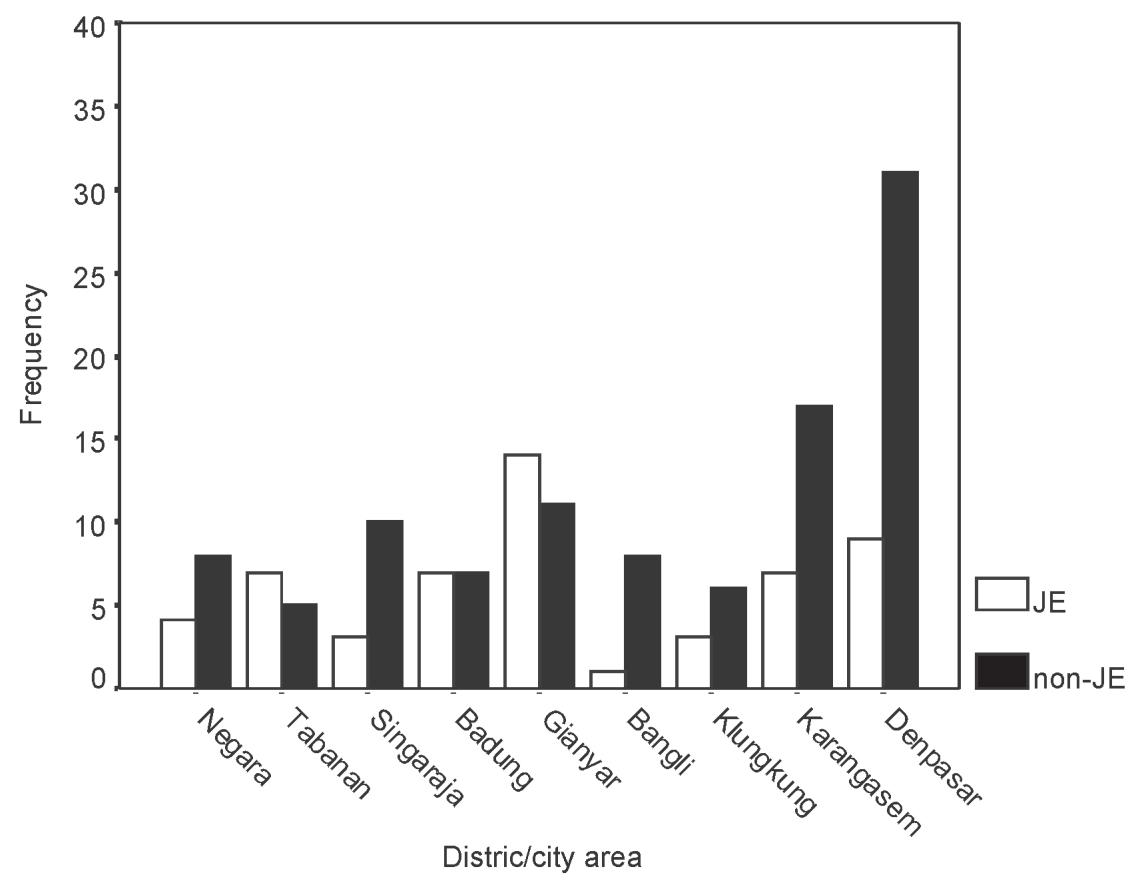

Figure 1. Distribution of JE AND NON-JE based on District/City AREA DURING THE PERIOD OF JULY 2001 TO JANUARY 2003

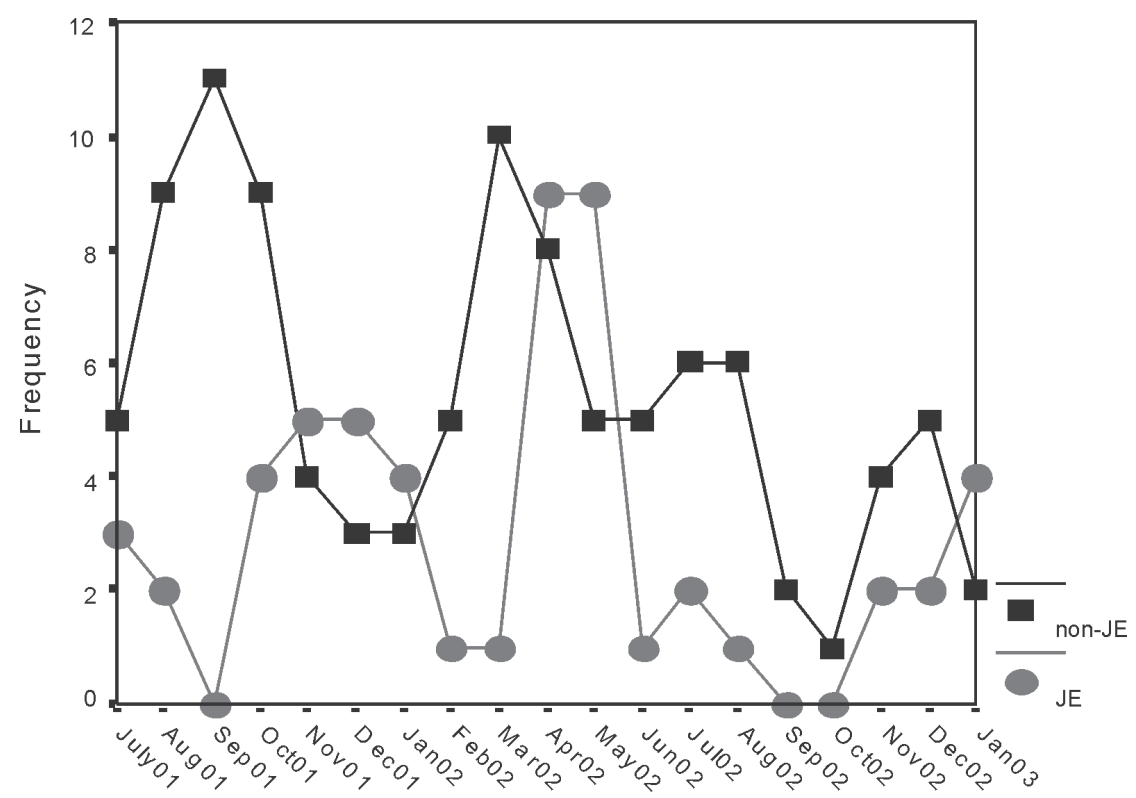

Figure 2. Monthly admission of JE, NON-JE In Bali surveillance HOSPITALS, DURING THE PERIOD OF JULY 2001 TO JANUARY 2003 
Our study showed that JE was endemic in Bali since JE appears almost every month, especially during the wet season in all districts, including the city of Denpasar. Among the tourists, a-10-year-old Australian girl, ${ }^{20}$ a-60-year-old Swedish woman, ${ }^{21}$ and a-50year-old Danish man, ${ }^{22}$ who stayed for two weeks, 10 days, and 12 days, respectively in Bali, experienced JE since they had not yet the immunity against JEV.

The case fatality rate of $7.3 \%$, which we observed, was less than that of reports in Kampangphet, Thailand (33\%), ${ }^{5}$ India (10\% to $\left.60 \%\right),{ }^{4}$ and Bangkok, Thailand (25.3\%). ${ }^{23}$ Death is presumed to result from infection, dysfunction, and destruction of neurons. Mortality is related to a short prodromal syndromes, deep coma, abnormalities in tone and breathing, and decerebrate posturing. ${ }^{18}$ According to Rao, ${ }^{19}$ ignorance kills more children than does JEV per se, where the main reason for high morbidity and mortality rates in India is improper or inadequate nursing care.

In our study of $55 \mathrm{JE}$ subjects, 25 (45.5\%) survived with disabilities such as paresis, spastic paralysis, decerebrated rigidity, verbal aphasia, and extrapyramidal syndromes. The majority of survivors had severe neurological sequelae, including polio-like flaccid paralysis. ${ }^{8}$ Of $144 \mathrm{JE}$ cases, 33 (23\%) had severe sequelae and 99 (68.8\%) had minor, moderate and severe sequelae. ${ }^{24}$

We note certain study limitations. First, the main shortcoming of this study is that mortality in JE cases may underestimate by the fact that death may to some extend largely occurred before the arrival in the hospital, therefore, the mortality rate may be lower than the true value. Most death may occur at home or on arrival due to the acute illness of its nature or management delay. Second, likewise mild JE cases manifesting only by febrile convulsions may invariably have been missed. This omission may have further contributed to the underestimation of true JE incidence in Bali. Community based study may be important to answer those gaps.

In conclusion, around one-third of patients diagnosed as having encephalitis are positively diagnosed as JE. The highest prevalence is in Gianyar. Peak prevalence of JE are in April and May 2002. Almost a half of JE subjects survived with disability. Pig owning and rice farming are the associated factors.

\section{Acknowledgments}

We thank Dr. Steve Rosenthal for his invaluable advise on the design of the study; Ms. Wayan Yastini, Ms. I. Gst Ayu Joni, and Ms. Panor Srisongkram for their assistance in performing the diagnostic test; Ms. Ida Ayu Made Ratna Dewi, SSi and Mr. I Dewa Gede Sura Dharma, SKM for assistance in specimen transportation and coordination with pediatricians in Bali. We thank the following colleagues for their participation and contribution during this investigation: Department of Child Health, Gianyar District Hospital, dr. I Md. Sidia, SpA, dr. I.B. Maharda, SpA and dr. A.A. Oka Lely, SpA, Department of Child Health, Badung District Hospital, dr. Nengah Supatra, SpA, dr. Wayan Bikin Suryawan, SpA, and dr. Nyoman Sugita, SpA, Department of Child Health, Klungkung District Hospital, dr. Wayan Murya, SpA, Department of Child Health, Bangli District Hospital, dr. Sunarka, SpA and dr. A. A. N. Prayoga, SpA, Department of Child Health, Tabanan District Hosptial, dr. Wayan Metri, SpA, Department of Child Health, Singaraja District Hospital, dr. I Kt. Budiyasa, SpA and dr. Gst. N. Susanta, SpA, Department of Child Health, Negara District Hospital, dr. I Komang Kari, SpA, Department of Child Health, Amlapura District Hosptial, dr. Rubiana Sukardi, SpA, Department of Child Health, Army Hospital of Bali Province, dr. Kt. Wirata, SpA, Department of Child Health, Sanglah Hospital, Medical School, Udayana University. Most of all, we thank the children and families who participated in the study.

\section{References}

1. Reppley MC. Epidemiology of Japanese encephalitis. In: Matheson Commission. Epidemic encephalitis. 3rd report. New York: Columbia University; 1993. p. 157.

2. Igarashi A. Control of Japanese encephalitis in Japan: Immunization of humans and animal, and vector control. In: Mackenzie JS, Barrett ADT, Denbel V, editors. Japanese encephalitis and West Nile Viruses. 1st ed. Springer-Verlag Berlin Eidenberg.

3. Solomon T, Dung NM, Kneen R, Gainsborough M, Vaugh DW, Khankh NT. Japanese encephalitis. J Neural Neurosurg Psychiatry 2000;68:405-15.

4. Reuben R, Gajanana A. Japanese encephalitis in India. Indian J Pediatr 1997;64:243-51.

5. Burke DS, Lorsomrudee W, Leake CJ, Hoke CH, Nisalak A, Chongswasdi, et al. Fatal outcome in Japanese encephalitis. Am J Trop Med Hyg 1985;34:1203-10. 
6. Dapeng L, Jindows, Huijun Y, Renguo Y, Ze W. Prognostic factor of early sequelae and fatal outcome of Japanese encephalitis. Southeast Asian J Trop Med Public Health 1995;26:694-8.

7. Weil ML, Toumanen E, Israele N, Rust R, Menkes JH. Infection of the nervous system. In: Menkes JH, Sarnat HB, editors. Child Neurology. 7th ed. Philadelphia: Lippincott Williams \& Wilkins; 2000. p. 467-626.

8. Solomon T, Kneen R, Dung NM, Khanh VC, Thuy TTN, Ha DQ, et al. Poliomyelitis-like illness due to Japanese encephalitis virus. Lancet 1998;351:1094-7.

9. Lubis I, Wuryadi S. Penyakit Japanese encephalitis pada anak-anak di dua rumah sakit di Jakarta. Bull Penelit 1981;11:18-22.

10. Kari K. Japanese encephalitis at Sanglah central hospital, Denpasar. Presented at 10th National Congress of Child Health; 1996 Jun 18-20; Bukittinggi, Indonesia.

11. Burke DS, Nisalak A. Detection of Japanese encephalitis virus immunoglobulin $\mathrm{M}$ antibodies in serum by antibody capture radioimmunoassay. J Clin Microbiol 1982;15:353-61.

12. Burke DS, Nisalak A, Ussery MA. Antibody capture immunoassay detection of Japanese encephalitis virus immunoglobulin $\mathrm{M}$ and $\mathrm{G}$ antibodies in cerebrospinal fluid. J Clin Microbiol 1982;16:1034-42.

13. Innis BC, Nisalak A, Nimmannitya S, Kusalerdchariya S, Chongswasdi V, Suntayakorn S, et al. An enzymlinked immunosorbent assay to characterize dengue infections where dengue and Japanese encephalitis cocirculate. Am J Trop Med Hyg 1989;40:418-27.

14. Hoke CH, Vaughan DW, Nisalak A, Intralawan P, Poolsuppasit S, Jongsawas $\mathrm{V}$, et al. Effect of high-dose dexamethason on the outcome of acute encephalitis due to Japanese encephalitis virus. J Infect Dis 1992;165:631-7.
15. Bell WE, McCormick WF. Neurologic infections in children. 2nd ed. Philadelphia: WB Saunders Company; 1981. p. 290-358.

16. Lee VH, Atmosodjono S, Rusmiarto S, Aep S, Semendra W. Mosquitoes of Bali island, Indonesia: Common species in the village environment. Southeast Asian J Trop Med Public Health 1983;14:298-307.

17. Vaugh DW, Hoke CH. The epidemiology of Japanese encephalitis: Prospects for prevention. Epidemiol Rev 1992;14:197-221.

18. Kumar R, Mathur A, Kumar A, Sharma S, Chakrabortys, Chaturvedi MC. Clinical features and prognostic indicator of Japanese encephalitis in children in Lucknow (India). Indian J Med Res 1990;91:321-7.

19. Rao PN, Saraswati I, Gopal KPV, Kishan RB, Ashok G. Nineteen years study of epidemiology of Japanese encephalitis in children of Andhra Pradesh from 1979 to 1977. Proceedings of the 38th National Conference of Indian Academy of Pediatrics; 2000 Jan 27-30, p. 207.

20. Macdonald WB, Tink AR, Ouvrier RA, Menser MA, de Silva LM, Naim H, et al. Japanese encephalitis after a two-week holiday in Bali. Med J Aust 1989;150:334-6.

21. Wittesjö B, Eitrem R, Niklasson B, Vene S, Mangiafico JA. Japanese encephalitis after a 10-day holiday in Bali. Lancet 1995;345:856.

22. Buhl Mr, Black FT, Anderson PL, Laursen A. Fatal Japanese encephalitis in Danish tourist visiting Bali for 12 days. Scand J Infect Dis 1996;28:189.

23. Thisyakorn U, Nimmannitya S. Japanese encephalitis in Thai children. Southeast Asian J Trop Med Pub Hlth 1985;16:93-7.

24. Solomon T, Dung MN, Kneen R, Thao LTT, Gainsborough M, Nisalak A, et al. Seizures and raised intracranial pressure in Vietnamese patients with Japanese encephalitis. Brain 2002;120:1084-93. 